\title{
Cross-Cultural Adaptation of the General Functioning Subscale of the McMaster Family Assessment Device
}

Muneer Gohar Babar ( $\sim$ muneer_babar@imu.edu.my )

International Medical University, School of Dentistry https://orcid.org/0000-0002-3012-187X

\section{Sobia Bilal}

International Medical University, School of Dentistry

Zamros Yuzadi Mohd Yusof

Universiti Malaya

Karuthan Chinna

Taylor's University

Jennifer Geraldine Doss

University Malaya, Faculty of Dentistry

Allan Pau

International Medical University, School of Dentistry

Research

Keywords: family functioning, Family Assessment Device, confirmatory factor analysis, reliability, construct validity, Malay

Posted Date: September 25th, 2020

DOl: https://doi.org/10.21203/rs.3.rs-79354/v1

License: (c) (i) This work is licensed under a Creative Commons Attribution 4.0 International License.

Read Full License 


\section{Abstract}

Background: The aim of the study was to conduct a cross-cultural adaptation and validation of the General Functioning Subscale (GF12) of the McMaster Family Assessment Device (FAD) into the Malay language.

Methods: The translation and adaptation procedure of the Malay GF12 was based on the dual-panel methodology. This involved conducting a bilingual panel (providing the initial translation into Malay language) followed by a lay panel (where items are assessed for comprehension and acceptability). A mixed-methods approach with exploratory sequential study design was employed.

Results: Two hundred and fifty-one families who have children in pre-schools (Tadikas) answered the Malay GF12. The KMO value for sampling adequacy was 0.81 , indicating the sample was adequate for factor analysis. The Malay GF12 demonstrated high internal consistency (Cronbach's alpha coefficient > $0.80)$. In the confirmatory factor analysis, the original 12 -item model did not fit very well. Alternatively, a 2factor-6-item model showed a sufficient fit. The two constructs comprised Positive Items and Negative Items.

Conclusions: The results indicate the feasibility of administering 6 of the 12 items of Malay GF12 (3 positively worded and 3 negatively worded) to measure family functioning in the Malaysian population.

\section{Background}

Families play a major role in the expression of variety of ailments including psychiatric and oral disorders 1,2 . Socioeconomic status and poor oral health habits of parents have been linked directly to the occurrence of dental caries among children. ${ }^{2-4}$. Nevertheless, the child's oral health and behaviour have received less attention from family functioning and relationships ${ }^{5}$. Family is the primary unit of socialization during childhood, and is central in shaping engagement in health behaviour, including physical activity. Thus, it has been propounded that a child's health status could be directly linked to parents health behaviour including disease and genetic composition ${ }^{6}$. Furthermore, families that are subjected to different ecocultural pathways may reflect altered socio-economic conditions and subsequent variations in resource allocation. As a result, personal interest, time, income generation, educational background and social network activities all play a significant role. Thus it becomes imperative to look into the family functioning and how the resources are utilized and their effects on the health ${ }^{6}$.

Family functioning may be described as a balance between family cohesion and family adaptability to challenges within the family and the environment ${ }^{5}$. Health literacy of a family may influence communication of health information to the family, individual health beliefs and health-related behaviour 7. A child is part of a larger family system and the family, in turn, is part of a broader neighbourhood or 
community system. Consequently, any changes in the family may affect the child and changes in the child development ${ }^{8}$.

Perceived family functioning can be studied extensively using a self-reported assessment tool, Family Assessment Device (FAD) ${ }^{9}$. The FAD is a 60 item measure that is built on McMaster Model of Family Functioning comprises six family functioning domains: general problem solving, communication, roles, affective responsiveness, affective involvement and behaviour control ${ }^{10,11}$.

A shortened version of the FAD comprising 12 items has been formulated to measure general family functioning with excellent psychometric properties ${ }^{12}$. General Functioning subscale (GF12) is a shortened version of FAD with all the domains but reduced items for rating. Each item is rated on a four point- Likert scale with indicators ranging from strongly agree to strongly disagree ${ }^{13}$. The GF12 is adapted into various languages for ease of application and usage with ethnic communities. The prominent translations incorporate Hispanic-Americans ${ }^{14}$, Hawaiian and Japanese American ${ }^{15}$ subpopulation and Euro-Asian communities ${ }^{16-20}$.

Various methods have been employed to appropriately translate the instrument for cross-cultural adaptation and implementation with respect to self-reported health outcome questionnaire ${ }^{21-24}$. Forward-backward (FB) translation method is the most popular method ${ }^{25}$. Another method utilized a consensus translation methodology with two different panels. This dual panel (DP) approach is first attempted with panel who are versed with bilingual skills that are native to the target translation and accompanied by a representative of the developers of the instrument. The second panel comprise subjects versed with multi-linguistic abilities but educationally possess average or below average literacy 26 .

An investigation of family functioning in the context of Malaysia's diverse family structures, from urban to rural, single parent to extended families, within a multi-racial society can provide an understanding of the multi-factorial causes of chronic non-communicable oral diseases, including caries. Rapid urbanization, such as that being witnessed in Malaysia, has considerable impacts on living conditions in terms of housing and access to health and social services, which in turn will impact on health outcomes 27. There is a need to measure the impact of family functioning on the health of the Malaysian population. The multi-dimensional nature and variability associated with the family functioning predisposes a complex background for a deliberate assessment. The GF12 instrument has been widely used in this pursuit, but translation and validation in local language is a requisite.

\section{Methods}

The intent of this study was to adapt cross-cultural attributes to the GF12 instrument of the FAD and subsequent psychometric validation in the Malay language. The methodology adopted mechanism elaborated from guidelines and strategies by Guillemin and colleagues ${ }^{28}$. The first step included a precise translation as outlined by the guidelines. This was followed by a pre-test method which involves a 
test of the cognitive attribute and subsequently, the process involves pilot testing. The Malay version was transcribed from the English version based on the semantic, operational and measurement equivalences.

\section{Translation of the English GF12 into Malay Language}

A dual panel approach was utilized. This method was suggested by Hunt et al ${ }^{22}$ and supported by Swaine-Verdier et al for a concept based translation ${ }^{23}$. Linguistic equivalence was not considered in this approach. The contemplation is based on the premise that obtaining "natural" translation for an item in a new language is a difficult proposition. Hence, a word that is equivalent to the conceptual meaning is usually sought. Further, the translation is attempted to harness words that are in common usage.

\section{The dual-panel translation procedure comprised the following main steps:}

Panel 1: Five bilingual healthcare professionals consisted of a nurse, a public health specialist, a community nutritionist, a dentist and a dental support assistant were invited to attend a one-day discussion forum to produce the first draft of the Malay GF12 that was conceptually equivalent with the English version.

Panel 2: This panel consisted of a monolingual nurse, a dental surgery assistant and three persons from the targeted community (lay people) with the Malay language as their first language. A one-day discussion forum was organized within the premise of the International Medical University (IMU). The focus of this group was to review the first draft of the Malay GF12 to ensure the translations were expressed in a natural, everyday Malay language. This thorough scrutiny of the translation process was facilitated by two members of the research team. At the end of the session, the panel agreed on the draft Malay GF12 with minor changes.

\section{Validation of the draft Malay GF12}

A mixed-methods approach with exploratory sequential study design was employed. Face validity and content validity of the draft Malay GF12 was tested using a pre-test qualitative mechanism. The reliability and construct validity in the assessment of psychometric properties was tested using a pilot methodology. At each stage, a signed informed consent was obtained from the participating parent/guardian of the child. The consent form and study information sheet were sent to the parents through the school. Confidentiality and safe record keeping were ensured to the participants at both data collection stages.

Pre-test: The pre-test of the draft Malay GF12 involved an expert panel of eight members (two general dentists, two dental public health specialists, two nurses, and two dental academicians) and a group of parents of preschool children. The objectives of the pre-test were to assess the presence of ambiguities in the translation process, identify items with inappropriate conceptual levels, and identify wordings that were confusing to understand ${ }^{24}$. The questionnaire was emailed to the eight-member expert panel who 
were bilingual. They were instructed to comment on the conceptual equivalence and wordings of the draft Malay GF12. As for the parents, they attended a focus group discussion (FGD) to assess whether the questionnaire purpose, instructions and items were relevant and easily understood, and the item concepts were culturally relevant. The FGD was audio recorded and field notes were taken to validate the findings. Interpretation biases and discrepancy in the observations was tackled using 'member check; approach. The two pre-test outcomes (expert panel and parents) were reviewed by the research team and the consensus draft of the Malay GF12 was finalized.

Pilot test: A total of 510 parents of 5-6-year-old children from 11 Tadikas (kindergartens) randomly selected in the Petaling district were invited to participate in the pilot test. As per the dictation of the pilot protocol, parents answered question related to their pre-school children and their socio-demographic status. The entire episode was conducted in the presence of a member of the research team. Subsequently, 15 parents were asked to answer the Malay GF12 questionnaire two weeks later.

\section{Data entry and analysis}

Pre-test: The data entry and analysis applied using NVivo-11 software. A textual data was obtained from the recorded data and field notes from the FGD using verbatim transcription method. A detailed thematic analysis followed the above procedure.

Pilot test: IBM Statistical Package for the Social Science (Chicago, IL, USA) version 25 software was used for data analysis. Scoring of the Malay GF12 was based on a 4-point Likert scale ( $1=$ strongly agree to 4 = strongly disagree). The scores for negative items were reversed and total score was calculated by summing up the scores of the 12 items. Descriptive statistics (frequency, mean and standard deviation) were used to describe parents' socio-demographic details. The psychometric properties of the Malay GF12 were assessed in terms of internal consistency, test-retest reliability, and construct validity. Cronbach's alpha coefficient measured the internal consistency of the Malay GF12. The homogeneity between the items was explored in this assessment. The statistical computations including intra-class correlation (ICC) coefficient, exploratory factor analysis, confirmatory factor analysis (CFA) were employed to analyse test-retest reliability, construct validity, assessment of the measurement equivalence of Malay GF12, respectively. The analysis examined the instrument factors and factor loadings including expressiveness of factor loadings with respect to the structure of GF12 through convergent and discriminant validity. IBM ${ }^{\circledR}$ SPSS ${ }^{\circledR}$ Amos $^{\text {TM }}$ software was utilized to perform the above computations. Amos $^{\text {TM }}$ uses the maximum likelihood estimation (MLE) method which requires the assumption of multivariate normality (MVN). Expressiveness of factor loadings, residual variances and modification indexes were analysed. The best model fit with value $<0.08$ is represented as the Root Mean Square Error of Approximation (RMSEA). Good results for the Comparative Fit Index (CFI) and the Tucker-Lewis Index (TLI) are within the range of $>0.90$. The Goodness-of-Fit statistic (GFI) calculates the proportion of variance that is accounted for by the estimated population covariance and GFI cut-off point of $\geq 0.90$ shows how closely the model comes to replicating the observed covariance matrix. The AGFI adjusts the GFI based upon degrees of freedom, and generally the values of $\geq 0.90$ indicate well-fitting models. Furthermore, Composite Reliability (CR) values > average variance Extracted for the items (AVE) values 
indicate good fit of the model. To test for discriminant validity, the magnitude of the shared variance between the final 2 constructs $\left(R^{2}\right)$ is checked to be less than the within construct variances (AVEs). A non-significant value for $\chi^{2}$, values as close as possible to 1.00 for adjusted goodness-of-fit index (AGFI), values higher than 0.95 for normed fit index (NFI) and comparative fit index (CFI), a value as close as possible to zero for standardized root mean square residual (SRMR), and a value lower than 0.05 for root mean square error of approximation (RMSEA) are indicative of a good fit between the estimated model and input data ${ }^{29}$. Hu et al noted a value of RMSEA as high as 0.08 and values for CFI ranging from 0.90 to 0.95 for an acceptable fit of a confirmatory factor model ${ }^{30}$.

\section{Results}

For the pre-test of the draft Malay GF12, all the eight members of the expert panel and the eight parents who were approached responded (100\% response rate). All parents were of Malay ethnicity. They found the translated version of GF12 in Malay language easy to adapt and simple. In item 1, the final Malay word for the word "sukar" (difficult) was changed to "susah" (a synonym of "sukar"), in item 2 the word "krisis" (crisis) was changed to "masalah" (a synonym of "krisis"), and in item 5 the word "gusar" (concern) was changed to "risau" (a synonym of "gusar"). Item 12 of the Malay version was rephrased from "Kami bersikap terbuka di antara satu sama lian" (We confide in each other) to "Kami selesa berkongsi masalah antara satu sama lain" which was conceptually equivalent. Table 1 shows the final Malay translation against the original version of GF12 subscale after final amendments were made based on decisions from the review committee. 
Table 1

The Malay translation items and the corresponding GF12 items.

\section{No English version}

$1 \quad$ Planning family activities is difficult because we misunderstand each other

2 In times of crisis we can turn to each other for support

3 We cannot talk to each other about the sadness we feel

$4 \quad$ Individuals are accepted for what they are

$5 \quad$ We avoid discussing our fears and concerns

6 We can express feelings to each other

$7 \quad$ There are lots of bad feelings in our family

8 We feel accepted for what we are

9 Making decisions is a problem for our family

10 We are able to make decisions about how to solve problems

11 We don't get along well together

12 We confide in each other

\section{Malay version}

Merancang aktiviti keluarga menjadi susah kerana kami tidak sefahaman.

Kami menyokong satu sama lain semasa ada kesukaran/masalah.

Kami tidak selesa berterus terang tentang kesedihan yang kami alami.

Setiap ahli keluarga diterima seadanya.

Kami mengelak dari membincangkan perasaan takut dan risau.

Kami selesa meluahkan perasaan antara satu sama lain.

Terdapat banyak perasaan kurang senang di dalam keluarga.

Kami rasa diterima seadanya.

Membuat keputusan adalah suatu kesukaran dalam keluarga kami.

Kami boleh membuat keputusan bagaimana untuk menyelesaikan masalah.

Kami tidak sehaluan antara satu sama lain.

Kami selesa berkongsi masalah antara satu sama lain.

For the pre-test, of the 510 parents who were approached, 251 parents agreed to participate (49.5\% response rate). The parents' children were almost equally distributed in terms of gender (male $=50.2 \%$, female $=49.8 \%$ ) and age (5-year-olds $=46.2 \%, 6$-year-olds $=53.8 \%)$. Majority of the parents $/$ guardians were working fulltime (56.6\%) or were housewives (45.4\%) and belonged to a low-income group (67.3\%). Table 2 shows the participants' socio-demographic information. The parents were of urban and rural backgrounds. All the respondents were Malays $(n=251)$ with the majority having education up to secondary school level (90\%), and nearly half were working full-time (55.6\%). 
Table 2

Sociodemographic characteristics of the children and their parents $(\mathrm{N}=251)$

\begin{tabular}{|lcc|}
\hline Variable & $\mathbf{n}$ & $\%$ \\
\hline Age of child/year & & \\
5 & 116 & 46.2 \\
6 & 135 & 53.8 \\
\hline Gender & & \\
Male & 126 & 50.2 \\
Female & 125 & 49.8 \\
\hline Ethnicity & & \\
Malay & 250 & 99.6 \\
Indian & 1 & 0.4 \\
\hline Parent's education level & & \\
Primary school & 7 & 2.8 \\
Secondary school & 202 & 80.5 \\
Tertiary education* & 24 & 9.5 \\
No Education & 18 & 7.2 \\
\hline Parent's employment status & & \\
Full-time working & 117 & 46.6 \\
Self-employed & 19 & 7.6 \\
Housewife & 114 & 45.4 \\
Part time & 1 & 0.4 \\
\hline *Vocational training, college, and university \\
\hline
\end{tabular}

The Cronbach alpha of the Malay GF12 was 0.89 . For test-retest reliability analysis, the ICC value was more than 0.75 . Factor analysis of the Malay GF12 revealed that for each item the highest correlation with at least one other item in the construct was between 0.3 and 0.9 indicating the items correlated adequately in the construct. The KMO value was 0.8 which is considered good. Two factors emerged from the analysis: factor 1 consisting of positively worded items $(2,4,6,8,10,12)$ and factor 2 consisting of negatively worded items $(1,3,5,7,9,11)$ (Table 3$)$. 
Table 3

Results from Exploratory Factor Analysis (EFA) of the Malay GF12 items.

\begin{tabular}{|c|c|c|c|}
\hline \multirow[t]{2}{*}{ No } & \multirow[t]{2}{*}{ Pattern Matrix } & \multicolumn{2}{|c|}{ Factors } \\
\hline & & 1 & 2 \\
\hline 12 & We confide in each other. & .920 & \\
\hline 6 & We can express feelings to each other. & .913 & \\
\hline 4 & Individuals are accepted for what they are. & .911 & \\
\hline 8 & We feel accepted for what we are. & .835 & \\
\hline 10 & We are able to make decisions about how to solve problems. & .777 & \\
\hline 2 & In times of crisis we can turn to each other for support. & .644 & \\
\hline 5 & We avoid discussing our fears and concerns. & & .784 \\
\hline 9 & Making decisions is a problem for our family. & & .778 \\
\hline 3 & We cannot talk to each other about the sadness we feel. & & .753 \\
\hline 7 & There are lots of bad feelings in the family. & & .743 \\
\hline 1 & Planning family activities is difficult because we misunderstand each other. & & .683 \\
\hline 11 & We don't get along well together. & & .676 \\
\hline
\end{tabular}

A theoretical model (Fig. 1) allowed for the application of confirmatory factor analysis and the results are shown below.

From the analysis, the value of Chi-square/df was more than 3, the CFI, TLI, GFI, AGFI values less than 0.9 respectively, and the RMSEA value was more than 0.08 indicating the model fit was not acceptable.

Based on the factor weights, two factors were extracted (Table 4).

Table 4

Factor weights extracted two factors.

\begin{tabular}{|lllllllllllll|}
\hline & Q12 & Q11 & Q10 & Q9 & Q8 & Q7 & Q6 & Q5 & Q4 & Q3 & Q2 & Q1 \\
\hline F & .097 & .022 & .048 & .014 & .045 & .022 & .123 & .012 & .042 & .009 & .025 & .006 \\
\hline
\end{tabular}

Items: $12,10,8,6,4,2$ are components of factor 2 and $11,9,7,5,3,1$ are components of factor 1 as per the description in the theoretical model (Fig. 2). 
Table 5

Factor Score Weights (Group number 1 - Default model)

\begin{tabular}{|ccccccccccccc|}
\hline & Q11 & Q9 & Q7 & Q5 & Q3 & Q1 & Q12 & Q10 & Q8 & Q6 & Q4 & Q2 \\
\hline F1 & .173 & .097 & .224 & .066 & .043 & .035 & .018 & .007 & .007 & .023 & .007 & .004 \\
\hline F2 & .008 & .004 & .010 & .003 & .002 & .002 & .151 & .062 & .057 & .194 & .057 & .033 \\
\hline
\end{tabular}

Chi-square/df $>3, \mathrm{CFI}, \mathrm{TLI}, \mathrm{GFI}, \mathrm{AGFI}<0.9$ and RMSEA $>0.08 \rightarrow$ model fit is not acceptable

Table 6

Final model as per the description in the theoretical model (Fig. 3).

\begin{tabular}{|lllll|}
\hline Factor & Items & FL & AVE & CR \\
\hline 1 & 6. We can express feelings to each other & 0.91 & 0.736 & 0.893 \\
& 8. We feel accepted for what we are & 0.81 & & \\
10. We are able to make decisions about how to solve problems & 0.85 & & \\
\hline 2 & 0.90 & 0.732 & 0.891 \\
7. There are lots of bad feelings in the family & 0.77 & & \\
9. Making decisions is a problem for our family & 0.89 & & \\
11. We don't get along well together & \multicolumn{2}{l}{} \\
\hline
\end{tabular}

In the confirmatory factor analysis, the model of theoretical structure (in Fig. 3), was acceptable. In the final model, the two-factor-three-item model was found to fit well. The first factor is a measure of Positive Items and the second factor is a measure of Negative Items. The AVE values were 0.736 and 0.732 , respectively. The correlation value between the two factors was 0.67 , which is less than the square roots of the AVE values. Hence there is sufficient discriminant validity between the two constructs. The minimum factor loading was 0.77 .

\section{Discussion}

The purpose of this study was to explore and undertake the cross-cultural adaptation and validation of the Malay GF12 of the FAD. The study findings indicate that the Malay GF12 consisting of 2 factors with 3 items in each factor is valid and reliable to assess family functioning in the Malaysian setting.

The translation and adaptation of the English GF12 into Malay version proceeded according to plan 22 . The two panels which comprised bilingual and research experts were able to produce the Malay translation of the GF12 without much difficulties. Bilingual panel demonstrated adequate ability in translation with respect to their educational and linguistic capabilities compared to the general population. This finding was in accordance to Streiner and colleagues observations ${ }^{31}$. 
In the pre-test, a few Malay items of the GF 12 were revised. Overall, the expert panel recommended that a revision be made to the wordings of Item 12 while the lay panel recommended that changes be made to a few words in item 1, item 5 and item 2 . These changes were necessary to promote the readability and understanding of the Malay version by the target population, while at the same time maintaining the conceptual equivalence of the items in the English version. The review panel comprising main investigator and other researchers reviewed and agreed to the changes and adjustments in the translated version.

In the confirmatory factor analysis, the original 12-item model did not produce a well-fitted model because the RMSEA value of 0.227 was larger than the recommended value of less than 0.05 for a wellfitted model ${ }^{32}$. Instead, a two-factor and six-item model showed a more sufficient fit. The results indicate the feasibility of administering six of the twelve items of the Malay GF12 (3 positively worded and 3 negatively worded items) to measure family functioning in the Malaysian population. Our study findings are different from the findings of the Italian GF-12 subscale validation which has a 4-factor model with the following domains: competence, emotional, communication, and centre-on-self ${ }^{16}$. A possible explanation could be attributed to the differences in education levels and cultures between the two populations which conceptualize normal family functioning differently ${ }^{33}$. To examine the latent structure of general functioning of the family (GFF), confirmatory factor analysis was applied to verify the number of underlying dimensions of the instrument (factors) and how the item-factor relationship (factor loadings) is manifested. The results showed that the two-factor-three-item model has good construct validity and reliability in the Malaysian context. Based on the confirmatory factor analysis data, the final two-factor-three-item model shows a better fit, with the exclusion of Item 1: "Planning family activities is difficult because we misunderstand each other", Item 2: "In times of crisis we can turn to each other for support", Item 3: "We cannot talk to each other about the sadness we feel", Item 4: "Individuals are accepted for what they are", Item 5: "We avoid discussing our fears and concerns", and Item 12: "We confide in each other", with residue values that correlate with that of other six items. This may indicate that these items represent similar ideas of the other items, therefore being redundant in this instrument. Different cultural norms regarding family functioning may have affected the results which may also vary according to socioeconomic status. Despite a good correlation, the items 1, 2, 3, 4, 5 and 12 were intended to be maintained and that would allow for decision-making in analysis phase.

The reliability of the Malay GF12 was tested in terms of internal consistency and test-retest reliability whereby findings were in agreement with the Spanish and French FAD-GF12 studies ${ }^{34,35}$. The Cronbach alpha of the Malay GF12 was 0.89 which indicates a high level of internal consistency supporting the previous findings of Spanish and Dutch versions ${ }^{20,36}$. For test-retest reliability analysis, the ICC value was more than 0.75 which is considered good and in agreement with the ICC value for the French FADGF12 ${ }^{35,37}$. Our findings concurred with similar studies by Georgiadis et al. (0.89) and Zubrick et al. (0.88) on the English version of GF12 subscale, respectively ${ }^{38,39}$. However, differences between different family members when responding to the questionnaire have been reported previously, therefore limiting the generalizability of our study findings to other cultures 40 . 
Malaysia is a multi-racial country consisting of Malays, Chinese, Indians and indigenous peoples. As the survey had been carried out on a representative sample of the Malay population, the scale may not be suitable for use by other ethnic groups. Further studies are recommended to assess the validity of the Malay GF12 across different cultural settings in the country and also on establishing the cut-off point between "pathological" and "healthy" family functioning in the Malaysian population.

\section{Conclusion}

The findings of this study indicate that 6 (3 positively worded and 3 negatively worded items) of the 12 items of the Malay GF12 have adequate psychometric properties to measure family functioning in the Malaysian context. As family functioning is embedded in the cultural context, further studies should compare groups across different cultural settings to increase the specificity of the index.

\section{Abbreviations}

GF12: General Functioning Subscale

FAD: Family Assessment Device

KMO: Kaiser-Meyer-Olkin Test

GFF: General Functioning of the Family

EFA: Exploratory Factor Analysis

AGFI: Adjusted Goodness-Of-Fit Index

NFI: Normed Fit Index

CFI: Comparative Fit Index

SRMR: Standardized Root Mean Square Residual

RMSEA: Root Mean Square Error of Approximation

TLI: Tucker-Lewis Index

GFI: Goodness-of-Fit statistic

CR: Composite Reliability

AVE: Average Variance Extracted

ICC: Intra-Class Correlation 


\section{Declarations}

\section{Ethics approval and consent to participate}

The study was approved by the International Medical University (IMU) Joint Research and Ethics Committee (IMU R 157-2014) and consent to participate from the study subjects were recorded.

\section{Consent for publication}

Consent to publish from the study subjects were recorded.

\section{Availability of data and materials}

All data generated or analysed during this study are included in this published article (and its supplementary information files).

\section{Competing interests}

The authors have no conflicts of interest.

\section{Funding}

This work was supported by the Fundamental Research Grant Scheme (FRGS) by Ministry of Education Malaysia under Grant FRGS/2/2014/SKK11/IMU/01/1.

\section{Authors' contributions}

Muneer Gohar Babar, Sobia Bilal, Zamros Yuzadi Mohd Yusof, Jennifer Geraldine Doss, Karuthan Chinna and Allan Pau contributed to the design, implementation, analysis and interpretation of the research. All authors discussed the results and contributed to the final manuscript.

\section{References}

1. Halvorsen JG. Self-report family assessment instruments: an evaluative review. Fam Pract Res J. 1991 Mar;11(1):21-55.

2. Mattila M-L, Rautava P, Ojanlatva A, Paunio P, Hyssälä L, Helenius $H$, et al. Will the role of family influence dental caries among seven-year-old children? Acta Odontol Scand. 2005 Apr;63(2):73-84.

3. Okada M, Kawamura M, Kaihara Y, Matsuzaki Y, Kuwahara S, Ishidori H, et al. Influence of parents' oral health behaviour on oral health status of their school children: an exploratory study employing a causal modelling technique. Int J Paediatr Dent. 2002 Mar;12(2):101-8.

4. Petersen PE. Sociobehavioural risk factors in dental caries - international perspectives. Community Dent Oral Epidemiol. 2005 Aug;33(4):274-9. 
5. Duijster D, O'Malley L, Elison S, Van Loveren C, Marcenes W, Adair PM, et al. Family relationships as an explanatory variable in childhood dental caries: A systematic review of measures. Caries Res. 2013;47(SUPPL. 1):22-39.

6. Christensen P. The health-promoting family: a conceptual framework for future research. Soc Sci Med. 2004;59(2):377-87.

7. Holland J, Mauthner M, Sharpe S, Health Education Authority (Great Britain). Family matters: communicating health messages in the family. Health Education Authority; 1996.

8. Alm A, Wendt LK, Koch G, Birkhed D. Prevalence of approximal caries in posterior teeth in 15-year-old Swedish teenagers in relation to their caries experience at 3 years of age. Caries Res. 2007:41(5):392-8.

9. Kabacoff RI, Miller IW, Bishop DS, Epstein NB, Keitner GI. A psychometric study of the McMaster Family Assessment Device in psychiatric, medical, and nonclinical samples. J Fam Psychol. 1990;3(4):431-9.

10. Epstein N, Bishop D, Levin S. The McMaster model of family functioning. J Marital Fam. 1978;

11. Miller IW, Ryan CE, Keitner GI, Bishop DS, Epstein NB. The McMaster Approach to Families: theory, assessment, treatment and research. J Fam Ther. 2000 May;22(2):168-89.

12. Byles J, Byrne C, Boyle MH, Offord DR. Ontario Child Health Study: Reliability and Validity of the General Functioning Subscale of the McMaster Family Assessment Device. Fam Process. 1988 Mar 1;27(1):97-104.

13. Epstein N, Baldwin L. The McMaster family assessment device. Marital Fam Ther. 1983;

14. Walrath CM, Franco E, Liao Q, Holden EW. Measures of Child Emotional and Behavioral Strengths and Family Functioning: A Preliminary Report on the Reliability and Validity of Their Spanish Translations. J Psychoeduc Assess. 2004;22(3):209-19.

15. Morris TM. Culturally sensitive family assessment: an evaluation of the family assessment device used with Hawaiian-American and Japanese-American families. Fam Process. 1990;29(1):105-16.

16. Roncone R, Rossi L, Muiere E, Impallomeni M, Matteucci M, Giacomelli R, et al. The Italian version of the Family Assessment Device. Soc Psychiatry Psychiatr Epidemiol. 1998;33(9):451-61.

17. Keitner GI, Fodor J, Ryan CE, Miller IW, Al E. A cross-cultural study of major depression and family functioning. Can J Psychiatry / La Rev Can Psychiatr. 1991;36(4):254-9.

18. Saeki, T., Asukai, N., Miyake, Y., Miguchi, M. \& Yamawaki S. Reliability and validity of the Japanese version of the Family Assessment Device (FAD). Arch Psychiatr Diagnosis Clin Eval. 2002;8:181192.

19. Shek DTL. Assessment of family functioning in chinese adolescents: The chinese family assessment instrument. Int Perspect Child Adolesc Ment Heal. 2002;2:297-316.

20. Wenniger WFM d. B, Hageman WJJM, Arrindell WA. Cross-national validity of dimensions of family functioning: First experiences with the Dutch version of the McMaster Family Assessment Device (FAD). Pers Individ Dif. 1993 Jun;14(6):769-81. 
21. Beaton D, Bombardier C, Guillemin F, Ferraz M. Guidelines for the process of cross-cultural adaptation of self-report measures. Spine (Phila Pa 1976). 2000;25(24):3186-91.

22. Hunt SM, Alonso J, Bucquet D, Niero M, Wiklund I, McKenna S, et al. Cross-cultural adaptation of health measures. Health Policy (New York). 1991;19(1):33-44.

23. Swaine-Verdier A, Doward LC, Hagell P, Thorsen H, McKenna SP. Adapting Quality of Life Instruments. Value Heal. 2004 Sep;7(s1):S27-30.

24. Wild D, Grove A, Martin M, Eremenco S, McElroy S, Verjee-Lorenz A, et al. Principles of Good Practice for the Translation and Cultural Adaptation Process for Patient-Reported Outcomes (PRO) Measures: Report of the ISPOR Task Force for Translation and Cultural Adaptation. Value Heal. 2005 Mar;8(2):94-104.

25. Acquadro C, Conway K, Hareendran A, Aaronson N. Literature Review of Methods to Translate HealthRelated Quality of Life Questionnaires for Use in Multinational Clinical Trials. Value Heal. 2008 May;11(3):509-21.

26. Hagell P, Hedin P-J, Meads DM, Nyberg L, McKenna SP. Effects of Method of Translation of PatientReported Health Outcome Questionnaires: A Randomized Study of the Translation of the Rheumatoid Arthritis Quality of Life (RAQoL) Instrument for Sweden. Value Heal. 2010 Jun;13(4):424-30.

27. Yiengprugsawan V, Caldwell BK, Lim LL-Y, Seubsman S, Sleigh AC. Lifecourse Urbanization, Social Demography, and Health Outcomes among a National Cohort of 71,516 Adults in Thailand. Int J Popul Res. 2011;2011:1-9.

28. Guillemin F, Bombardier C, Beaton D. Cross-cultural adaptation of health-related quality of life measures: Literature review and proposed guidelines. J Clin Epidemiol. 1993;46(12):1417-32.

29. Byrne BM. Structural Equation Modeling With AMOS. 2nd ed. New York: Routledge; 2013. 416 p.

30. Hu, Li-tze,Bentler PM. Fit indices in covariance structure modeling: Sensitivity to underparameterized model misspecification. Psychol Methods. 1998;3(4):424-53.

31. Streiner D, Norman G, Cairney J. Health measurement scales: a practical guide to their development and use. 5th ed. Oxford University ; 2014. 448 p.

32. Fabrigar, LR. Wegener, DT. MacCallum, RC. Strahan E. Evaluating the use of exploratory factor analysis in psychological research. Psychol Methods. 1999;4(3):272-99.

33. Jung M. Chinese American Family Therapy. 1st ed. San Francisco: CA: Jossey-Bass; 1998.

34. Pires T, Assis SG de, Avanci JQ, Pesce RP. Cross-Cultural adaptation of the General Functioning Scale of the Family. Rev saúde pública. 2016 Jun 27;50.

35. Speranza M, Guénolé F, Revah-Levy A, Egler P-J, Negadi F, Falissard B, et al. The French Version of the Family Assessment Device. Can J Psychiatry. 2012 Sep;57(9):570-7.

36. Barroilhet S, Cano-Prous A, Cervera-Enguix S, Forjaz MJ, Guillén-Grima F. A Spanish version of the Family Assessment Device. Soc Psychiatry Psychiatr Epidemiol. 2009 Dec 14;44(12):1051-65. 
37. Portney LG, Watkins MP. Foundations of clinical research: applications to practice. 3rd ed. Leslie G. Portney MPW, editor. Stamford, USA: Appleton \& Lange.; 1993. 892 p.

38. Georgiades K, Boyle MH, Jenkins JM, Sanford M, Lipman E. A multilevel analysis of whole family functioning using the McMaster Family Assessment Device. J Fam Psychol. 2008;22(3):344-54.

39. Zubrick S, Silburn S, Garton A, Burton P, Dalby R, Carlton J, et al. Western Australian Child Health Survey: Developing Health and Well-being in the Nineties. 1995.

40. Sawyer MG, Sarris A, Baghurst PA, Cross DG, Kalucy RS. Family assessment device: reports from mothers, fathers, and adolescents in community and clinic families. J Marital Fam Ther. 1988 Jul;14(3):287-96.

\section{Figures}

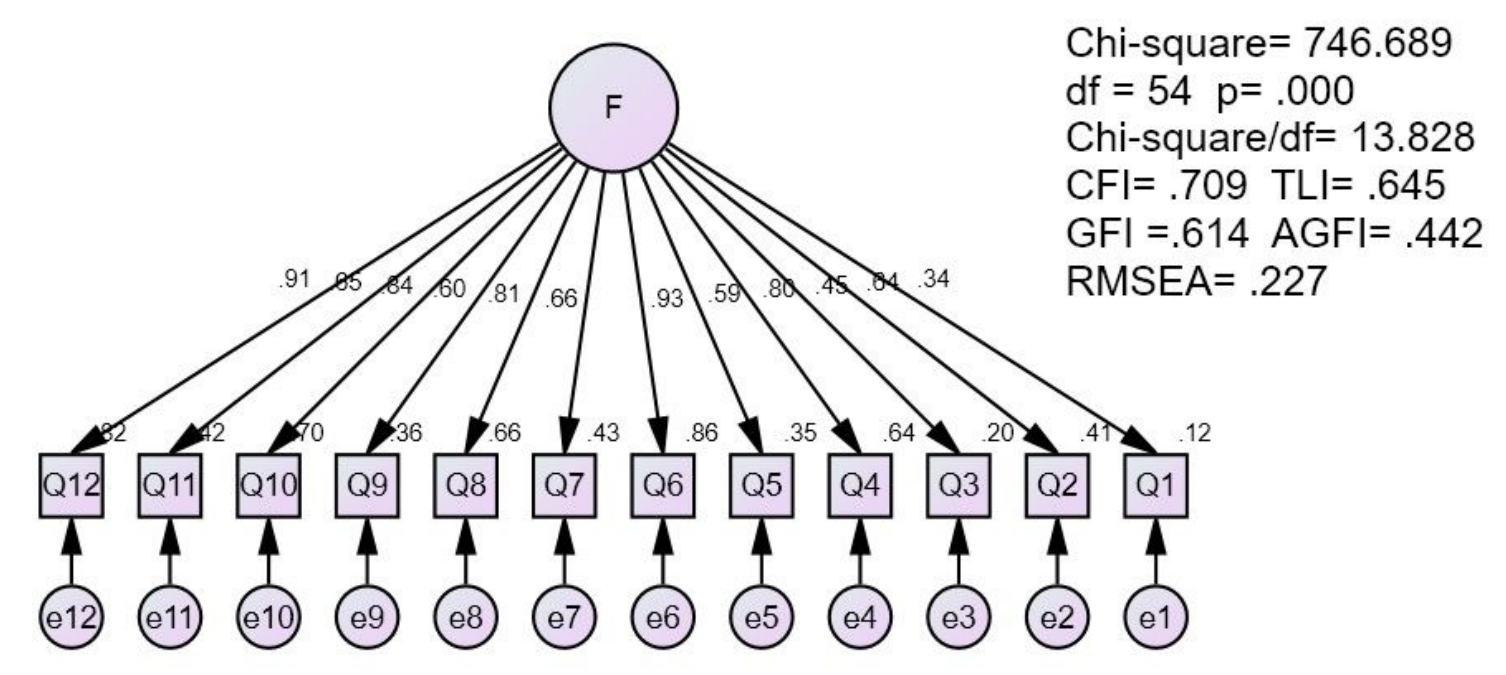

\section{Figure 1}

Theoretical model 


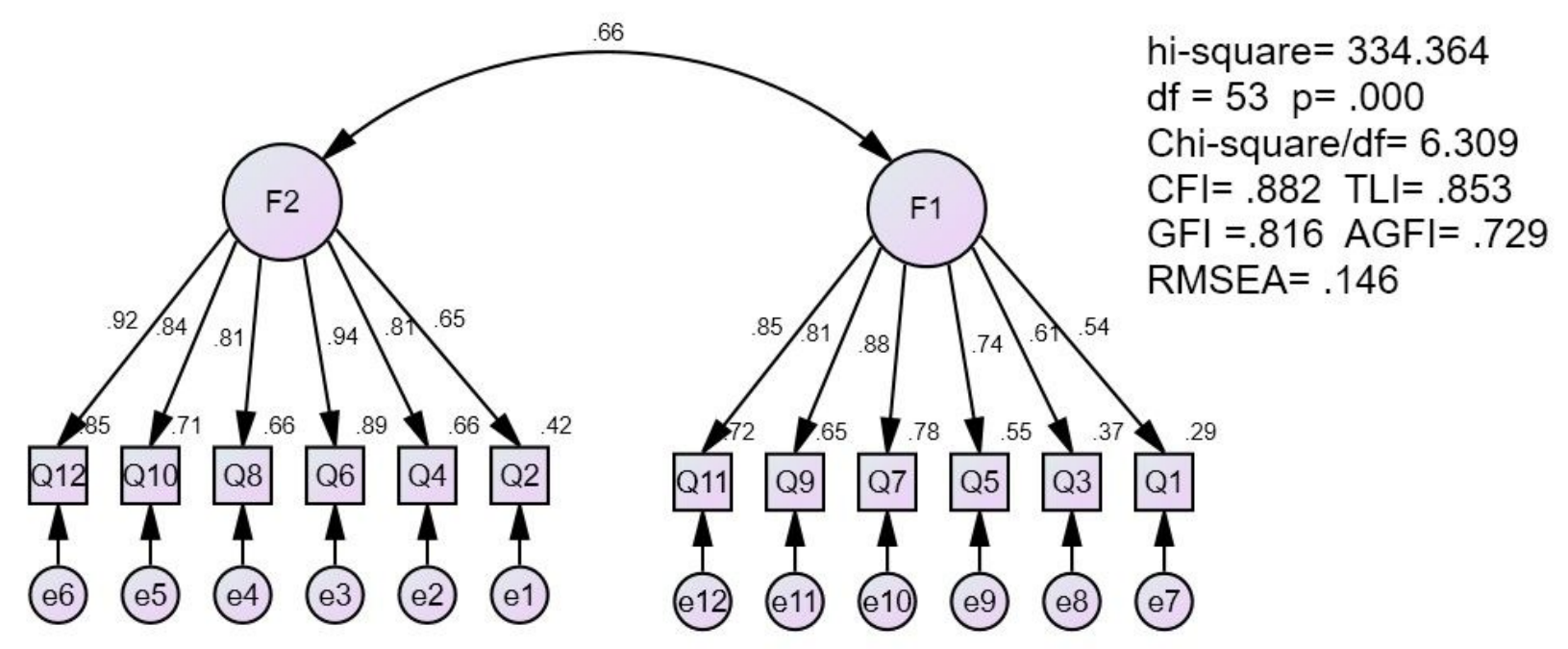

Figure 2

Two-factor Model in CFA 


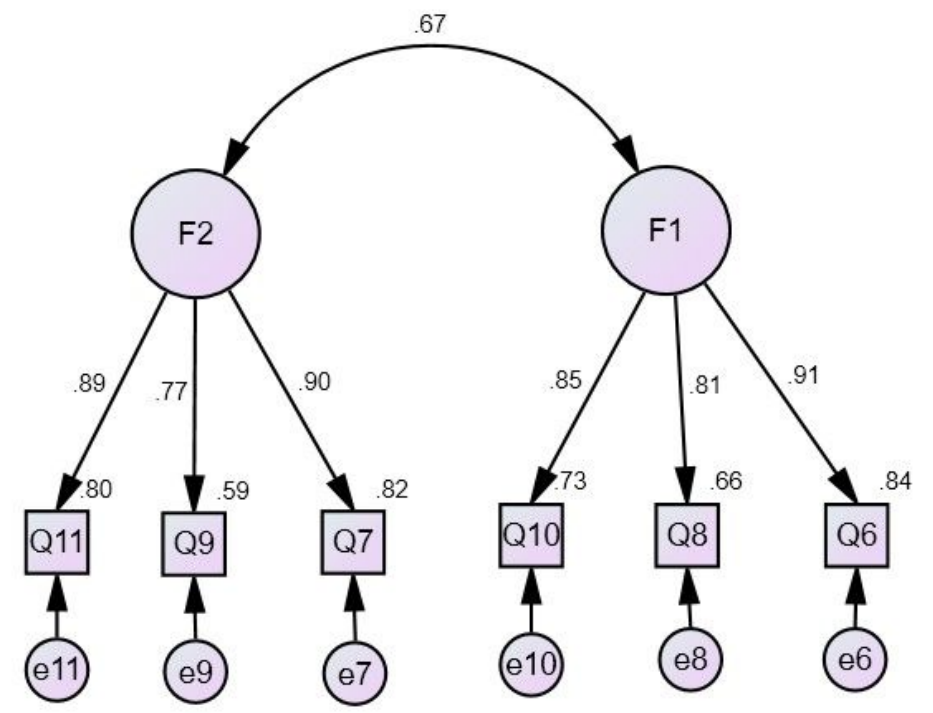

Chi-square $=23.053$

$\mathrm{df}=8 \mathrm{p}=.003$

Chi-square/df= 2.882

$\mathrm{CFI}=.985 \mathrm{TLI}=.973$

$\mathrm{GFI}=.972 \mathrm{AGFI}=.925$

RMSEA $=.087$

Figure 3

After correcting, Final model 